\title{
Al-Madãris
}

VOL. 1, NO. 12020

E-ISSN: 2745-9950

https://journal.staijamitar.ac.id/index.php/almadaris

\section{KONTRIBUSI MANAJEMEN PEMBIAYAAN DAN IKLIM MADRASAH TERHADAP PENINGKATAN MUTU PENDIDIKAN MADRASAH ALIYAH NEGERI DI ACEH UTARA}

\author{
Nurmadiah \\ Madrasah Tsnawiyah Negeri 3 Aceh Utara \\ noermaacut@gmail.com
}

\begin{abstract}
This research is a descriptive quantitative study with an ex post facto design. The study population was 120 public madrasah aliyah teachers from each state madrasah aliyah in all districts of North Aceh. The research sample was selected from the population of curriculum representatives, student representatives, infrastructure representatives, public relations representatives and financial managers in 6 State Madrasah aliyah in North Aceh Regency. The hypothesis was analyzed with the help of SPSS 18 for windows at a significant level of 0.05. Based on the data analysis and hypothesis testing conducted, it is found that: there is a significant contribution between financial management towards improving the quality of madrasah, the results of this study are the value of Sig. amounting to 0,000. Therefore, the Sig. $0.000<0.05$, it can be said that the value of the WMS calculation which is in the very good category, there is a significant contribution between the madrasah climate and the improvement of the quality of the madrasah, in this study the Sig. amounting to 0,000. Therefore, the Sig. $0.000<0.05$, it can be said that it can be said that from the value obtained from the WMS calculation which is in a very good category and there is a significant contribution between financing management and madrasah climate significantly to improving the quality of madrasah, then the Sig. 0.021 $<0.05$, it can be said that there is a significant contribution between financial management and madrasah climate significantly to improving the quality of madrasah, thus it can be said that the research was successful.
\end{abstract}

Keywords: Funding Management, Madrasah Climate and Madrasah Quality

$\overline{\text { Al-Madãris, Volume l (1), } 2020}$ 


\section{A. Pendahuluan}

Pendidikan mempunyai peranan sangat penting dalam meningkatkan kualitas sumber daya manusia. Pendidikan mempengaruhi secara penuh pertumbuhan ekonomi suatu bangsa. Dalam meningkatkan kualitas manusia Indonesia, pemerintah tidak merupakan satu sistem yang lepas dengan pihak swasta dan masyarakat. Hubungan yang tidak terpisahkan dalam peranannya untuk meningkatkan pemerataan dan mutu pendidikan. Sementara itu, pendidikan nasional kita dihadapi kepada masalah antara lain peningkatan kualitas, pemerataaan kesempatan, keterbatasan anggaran yang tersedia dan belum terpenuhi sumber daya dari masyarakat secara profesional sesuai dengan prinsip pendidikan sebagai tanggung jawab bersama antara pemerintah, masyarakat dan orang tua. (Nanang Fattah, 2000: 77).

Sebagai bagian dari sistem pendidikan nasional, keberhasilan madrasah dalam meningkatkan mutu pendidikannya akan memberikan kontribusi dalam upaya peningkatan mutu pendidikan nasional. Namun, disadari bahwa dalam melaksanakan upaya tersebut tentunya tidak terlepas dari berbagai permasalahan. Permasalahan yang dihadapi sekolah-sekolah umum lainnya, salah satu permasalahan yang dihadapi oleh madrasah saat ini adalah mutu pendidikan masih tidak sesuai dengan yang diharapkan. Hal ini seperti yang diungkapkan oleh Natsir Armaya Siregar dan Mohd. Sitompul bahwa meskipun perkembangan madrasah telah cukup menggembirakan akan tetapi dari segi mutu masih belum memuaskan atau kadang-kadang memprihatinkan (Muzayyin Arifin, 2003:150160). Bermutu atau tidaknya pendidikan di madrasah tidak lepas dari berbagai aspek yang terkait dengan kehidupan madrasah. Keuangan dan pembiayaan merupakan salah satu aspek yang secara langsung dapat menunjang efektivitas dan efisiensi pengelolaan pendidikan di madrasah. Pembiayaan merupakan salah satu faktor penentu bagi terlaksananya proses pendidikan yang pada gilirannya berdampak terhadap peningkatan mutu..

Meskipun tidak sepenuhnya masalah keuangan akan berpengaruh secara langsung terhadap kualitas sekolah, terutama berkaitan dengan sarana dan prasarana pembelajaran. Dalam kaitan ini, tuntutan reformasi adalah pendidikan yang murah dan berkualitas. Namun pendidikan yang berkualitas senantiasa memerlukan dana yang cukup banyak. Sejalan dengan kebijakan otonomi daerah yang menyerahkan masalah pendidikan ke daerah dan sekolah masing-masing, Masalah keuangan pun menjadi kewenangan yang diberikan secara langsung dalam pengelolaannya kepada sekolah.

Hal ini terkait juga dengan rendahnya mutu pendidikan madrasah dan tidak lepas dari rendahnya SDM yang dimiliki madrasah itu sendiri. Hasil temuan tim Asian Development Bank (Balitbang RI, 2013:59-75) menyebutkan bahwa banyak siswa-siswi madrasah berasal dari keluarga petani dan keluarga berstatus ekonomi rendah. Mereka masuk madrasah karena tidak diterima di sekolah umum akibat nilai UN rendah. Siswa madrasah dalam beberapa kasus, memiliki sifat yang bisa dikategorikan memberi andil dalam masalah pendidikan madrasah. Motivasi yang rendah dan sikap yang pasif dalam belajar serta kurangnya kesadaran pada pendidikan yang berorientasi ke masa depan merupakan kendala yang dihadapi dunia pendidikan madarasah.

Al-Madaris, Volume l (1), 2020 
Sementara, minimnya sarana dan prasarana penunjang pendidikan seperti ruang belajar, perpustidakaan, dan laboratorium yang ditunjang dengan rendahnya kualifikasi guru dan kepala madrasah. Merupakan sederetan penyebab rendahnya prestasi madrasah. Padahal, rendahnya mutu pendidikan madrasah sedikit-banyak memiliki andil bagi rendahnya mutu pendidikan nasional.

Manajemen pembiayaan madrasah merupakan aspek yang penting dan tidak dapat dipisahkan dari proses manajemen pendidikan secara keseluruhan. Pada hakikatnya, anggaran dan pembiayaan madrasah merupakan penjabaran dari program madrasah dalam bentuk angka-angka yang akan dipertanggungjawabkan bersama pencapaian program pada akhir tahun anggaran.

Sumber keuangan dan pembiayaan pada madrasah secara garis besar dapat dikelompokkan atas beberapa sumber, yaitu (1) pemerintah, baik pemerintah pusat melalui APBN melalui Dana Isian Pelaksanaan Anggaran (DIPA), dan pemerintah daerah melalui APBD bidang pendidikan; (2) orang tua dan masyarakat; (3) dana masyarakat; (4) usaha ekonomi madrasah; dan (4) sumber lain yang tidak mengikat.

Dalam implementasi manajemen berbasis madrasah, manajemen pembiayaan harus dilaksanakan dengan baik dan teliti. Mulai dari tahap perencanaan, penyusunan penggunaan anggaran, sampai pengawasan dan pertanggungjawaban sesuai dengan ketentuan yang berlaku agar semua dana yang diperoleh madrasah benar-benar dimanfaatkan secara tertib, efektif, efisien, transparan dan akuntabel.

\section{B. Review Literatur}

\section{Managemen Pembiayaan}

Manajemen didefinisikan sebagai suatu proses sosial, yang direncanakan untuk menjamin kerjasama, partisipasi, intervensi dan keterlibatan orang lain dalam mencapai sasaran tertentu atau yang telah ditetapkan dengan efektif. Manajemen sebagai suatu proses sosial meletakkan bobotnya pada interaksi orang-orang baik orang-orang yang berada di dalam maupun di luar lembaga atau yang berada di atas maupun di bawah posisi operasional seseorang (Iwa Sukiswa, 1986:13).

Proses manajemen terdiri dari empat unsur, yaitu: pertama, perencanaan meliputi penciptaan, penyusunan program dan penyusunan proyek. Kedua, pengorganisasian meliputi perakitan sumber dan pengstafan. Ketiga, pengarahan meliputi motivasi, supervise dan koordinasi. Keempat, pengawasan meliputi penganggaran, pelaporan dan evaluasi.

\section{Iklim Madrasah}

Iklim secara bahasa adalah kondisi rata-rata cuaca berdasarkan waktu yang panjang untuk suatu lokasi di bumi atau planet lain. Studi tentang iklim dipelajari dalam klimatologi. Iklim di suatu tempat di bumi dipengaruhi oleh letak geografis dan topografi tempat tersebut.

Untuk mewujudkan iklim masdrasah/sekolah yang kondusif dan inovatif dalam mendukung pembelajaran diperlukan strategi. Mengacu pada agenda

$\overline{\text { Al-Madãris, Volume l (1), } 2020}$ 
perubahan yang ditetapkan oleh pemerintah dalam mewujudkan iklim sekolah yang kondusif dan menunjang pencapaian tujuan pendidikan dapat dilakukan melalui program yang mencakup level kelas (regulator), level profesi (mediator), dan level sekolah (manajemen).

Iklim madrasah adalah persepsi kolektif terhadap kualitas dan karakter dari kehidupan madrasah. Dalam penelitian ini indikator yang digunakan untuk mengukur iklim madrasah adalah dengan menggunakan dimensi yang yang dikemukakan oleh coben, dengan alasan bahwa indikator tersebut merupakan indikator yang oleh penulis dipandang lebih terbaru dan lebih dapat menggambarkan ukuran dari konsep iklim madrasah 10 dimensi tersebut dikelompokkan ke dalam empat katagori, yaitu: (1) Kenyamanan, (2) Pembelajaran, (3) Hubungan antar pribadi dan (4) Lingkungan lembaga.

\section{Mutu Pendidikan}

Defenisi mutu memiliki konotasi yang bermacam-macam bergantung orang yang memakainya. Mutu berasal dari bahasa latin yakni "Qualis" yang berarti what kind of (tergantung kata apa yang mengikutinya). Mutu menurut Deming ialah kesesuaian dengan kebutuhan. Mutu menurut Juran ialah kecocokan dengan kebutuhan (Husaini Usman, 2006: 407).

Secara institusional, kemajuan suatu lembaga pendidikan lebih ditentukan oleh pimpinan lembaga tersebut daripada oleh pihak lain, tetapi dalam proses pembelajaran, guru berperan paling menentukan melebihi metode apalagi materi. Urgensi guru dalam proses pembelajaran ini terlukis dalam ungkapan Arab, yang pernah disampaikan A. Malik Fadjar, al-Tharîqah Ahammu min al-Mâddah walakinna al-Muddaris Ahammu min al-Tharîqah (Metode lebih penting dari pada materi, namun guru jauh lebih penting daripada metode)( Mujamil Qomar, 2007:57).

Peranan yang sangat penting dari guru itu bisa menjadi potensi besOar dalam memajukan atau meningkatkan mutu pendidikan Islam maupun sebaliknya, bisa menghancurkannya. Ketika guru itu benar-benar profesional dan diame-manage dengan baik, mereka makin bersemangat dalam menjalankan tu tugasnya mendidik bahkan rela melakukan inovasi-inovasi pembelajaran untuk mewujudkan keberhasilan peserta didik. Namun, jika mereka terlantar akibat tindakan pimpinan, mareka justru bisa menjadi penghambat paling serius terhadap proses dan mutu pendidikan Islam. Ke mana arah sikap guru ini sangat tergantung pada kualitas manajemen personalia. Hal ini terkait erat dengan pelayanan. Tujuan ini menunjukkan adanya keseimbangan antara kerja dengan situasi kerja. Pendayagunaan ini tidak bersifat pemaksaaan fisik, tetapi lebih merupakan strategi kerja yang tetap mempertimbangkan unsur-unsur manusiawi. Apalagi tenaga kependidikan tersebut berupa manusia yang tidak bisa disamakan dengan mesin, sehingga membutuhkan sentuhan-sentuhan rohani yang menyenangkan. Sebaliknya, situasi yang menyenangkan tersebut bisa meringankan beban-beban kerja yang selama ini dapat mengganggu kerja pegawai.

$\overline{\text { Al-Madaris, Volume l (1), } 2020}$ 


\section{Metodelogi}

Jenis penelitian ini adalah penelitian kuantitatif deskriptif. Penelitian kuantitatif adalah penelitian yang menggunakan pendekatan deduktif. Penelitian ini merupakan penelitian dengan desain ex post facto. Penelitian ini mencari data empiris yang sistematik. Dalam penelitian ini peneliti tidak dapat mengontrol langsung variabel bebas karena peristiwanya telah terjadi dan sifatnya tidak bisa dimanipulasi. Metode yang digunakan dalam penelitian ini, adalah metode survey melalui bantuan kuesioner. Lokasi penelitian bertempat di Madrasah Aliyah Negeri (MAN) Kabupaten Aceh Utara. Penarikan sampel dalam penelitian ini mengunakan sampel secara acak (random purposif sampling). Sampel adalah sebagian dari jumlah dan karakteristik yang dimiliki oleh populasi. Berdasarkan pengertian tersebut, sampel dipilih dari populasi wakil kurikulum, wakil kesiswaan, wakil sarana prasarana, wakil humas dan pengelola keuangan yang terdapat pada enam Madrasah aliyah Negeri di Kabupaten Aceh Utara. Penelitian yang dilakukan untuk mendapatkan data yang baik dilakukan dengan langkahlangkah sebagai berikut: 1. Persiapan, 2. Menentukan sampel penelitian, 3. Menyusun instrumen penelitian, 4. Uji coba instrumen penelitian, 5. Melaksanakan pengumpulan data dan menyebarkan kuesioner/angket penelitian kepada sampel penelitian, 6. Menganalisis data dengan menggunakan teknik analisis data yang tepat dan menguji hipotesis penelitiannya, 7 . Mendeskripsikan hasil penelitian dalam bentuk laporan penelitian sebagai sebuah karya ilmiah. Pengumpulan data dalam penelitian ini diperoleh melalui angket, yaitu untuk memperoleh iklim madrasah dan peningkatan mutu pendidikan. Pengumpulan data dilakukan dalam tiga tahap, pertama yaitu mengumpulkan data tentang manajemen pembiayaan, kedua iklim madrasah dan ketiga tahap mengumpulkan data tentang peningkatan mutu pendidikan. Analisis data mengunakan bantuan SPSS 18.0 for windows, yang digunakan dalam analisis data variable manajemen pembiayaan $\left(\mathrm{X}_{1}\right)$, variabel iklim sekolah (X2), dan variabel mutu sekolah (Y)

\section{Hasil Penelitian}

\section{Kecenderungan Variabel}

Kecenderungan variabel ditentukan berdasarkan teori Anas Sudijono yang mengatakan bahwa skor dapat diklasifikasikan dengan kriteria meliputi (1) tingkat tinggi: dari mean + 1 SD ke atas, (2) tingkat sedang: dari mean - 1 SD sampai + 1 SD, (3) tingkat rendah: dari mean - 1 SD ke bawah 1 (Sutrisno Hadi,1993: 135). Dengan demikian, kecenderungan masing-masing variabel adalah sebagai berikut.

a. Kecenderungan Variabel Manajemen Pembiayaan

Perhitungan rekapitulasi data tentang manajemen pembiayaan, diperoleh tingkat kecenderungan variabel manajemen pembiayaan (Xl) di Madrasah Aliyah Negeri sebagaimana yang terdapat pada tabel berikut ini.

$\overline{\text { Al-Madaris, Volume l (1), } 2020}$ 
Tabel 4.8. Tingkat Kecenderungan Manajemen Pembiayaan

\begin{tabular}{cccc}
\hline Katagori & Klasifikasi Skor & Jumlah & F Relatif \% \\
\hline Tinggi & $38-40$ & 19 & $35 \%$ \\
\hline Sedang & $32-34$ & 16 & $30 \%$ \\
\hline Rendah & $30-31$ & 19 & $35 \%$ \\
\hline & Jumlah & 54 & $100 \%$
\end{tabular}

Sumber: Hasil perhitungan rekapitulasi tingkat kecenderungan variabel manajemen pembiayaan

Berdasarkan data di atas dapat diketahui bahwa kecenderungan variabel manajemen pembiayaan di Madrasah Aliyah adalah sebanyak $35 \%$ berada pada kategori tinggi, $29 \%$ sedang, dan $35 \%$ rendah. Dengan demikian, kecenderungan variabel manajemen pembiayaan berada pada kategori tinggi dan rendah.

b. Kecenderungan Variabel Iklim Madrasah

Perhitungan rekapitulasi data tentang manajemen pembiayaan, diperoleh tingkat kecenderungan variabel Iklim Madrasah (X2) di Madrasah Aliyah Negeri sebagaimana yang terdapat pada tabel berikut ini.

Tabel 4.9. Tingkat Kecenderungan Iklim Madrasah

\begin{tabular}{cccc}
\hline Katagori & Klasifikasi Skor & Jumlah & F Relatif \% \\
\hline Tinggi & $38-40$ & 21 & $40 \%$ \\
\hline Sedang & $32-35$ & 31 & $60 \%$ \\
\hline Rendah & $30-31$ & 2 & $0 \%$ \\
\hline & Jumlah & 54 & $100 \%$ \\
\hline
\end{tabular}

Sumber: Hasil perhitungan rekapitulasi tingkat kecenderungan variabel iklim madrasah

Berdasarkan data di atas dapat diketahui bahwa kecenderungan variabel Iklim Madrasah di Madrasah Aliyah adalah sebanyak $40 \%$ berada pada kategori tinggi, $31 \%$ sedang, dan $0 \%$ rendah. Dengan demikian, bahwa kecenderungan variabel manajemen pembiayaan berada pada kategori sedang.

c. Kecenderungan Variabel Mutu Pendidikan

Perhitungan rekapitulasi data tentang manajemen pembiayaan, diperoleh tingkat kecenderungan variabel Iklim Madrasah (X2) di Madrasah Aliyah Negeri sebagaimana yang terdapat pada tabel berikut ini.

Tabel 4.10. Tingkat Kecenderungan Mutu Pendidikan

\begin{tabular}{cccc}
\hline Katagori & Klasifikasi Skor & Jumlah & F Relatif \% \\
\hline Tinggi & $58-60$ & 35 & $65 \%$ \\
\hline Sedang & $54-56$ & 10 & $19 \%$ \\
\hline Rendah & $47-51$ & 9 & $16 \%$ \\
\hline & Jumlah & 54 & $100 \%$ \\
\hline
\end{tabular}

Sumber: Hasil perhitungan rekapitulasi tingkat kecenderungan variabel mutu pendidikan 
Berdasarkan data di atas dapat diketahui bahwa kecenderungan variabel mutu pendidikan di Madrasah Aliyah adalah sebanyak $65 \%$ berada pada kategori tinggi, $19 \%$ sedang, dan $16 \%$ rendah. Dengan demikian, bahwa kecenderungan variabel mutu pendidikan berada pada kategori tinggi.

\section{Hasil Pengujian Hipotesis}

1. Terdapat Konstribusi yang Signifikan antara Manajemen Pembiayaan terhadap peningkatan Mutu Madrasah.

Hipotesis statistik yang diuji adalah:

Ho: $\mu \mathrm{A}_{1}=\mu \mathrm{A}_{2}$

$\mathrm{Ha}: \mu \mathrm{A}_{1} \neq \mu \mathrm{A}_{2}$

Maka, dapat dikatakan bahwa hasil pengujian menolak Ho atau menerima Ha. Hal ini terlihat dari kecenderungan variabel manajemen pembiayaan di Madrasah Aliyah adalah sebanyak $35 \%$ berada pada kategori tinggi, $29 \%$ sedang, dan $35 \%$ rendah. Dengan demikian, bahwa kecenderungan variabel manajemen pembiayaan berada pada kategori tinggi dan rendah.

2. Terdapat Konstribusi yang signifikan antara Iklim Madrasah terhadap peningkatan Mutu Madrasah.

Hipotesis statistik yang diuji adalah:

Ho : $\mu \mathrm{A}_{1}=\mu \mathrm{A}_{2}$

$\mathrm{Ha}: \mu \mathrm{A}_{1} \neq \mu \mathrm{A}_{2}$

Maka dapat dikatakan bahwa hasil pengujian menolak Ho atau menerima $\mathrm{Ha}$. Hal ini di tandai dari kecenderungan variabel iklim madrasah di Madrasah Aliyah adalah sebanyak $40 \%$ berada pada kategori tinggi, $31 \%$ sedang, dan $0 \%$ rendah. Dengan demikian, dapat disimpulkan bahwa kecenderungan variabel manajemen pembiayaan berada pada kategori sedang.

3. Terdapat Konstribusi yang Signifikan antara Manajemen Pembiayaan dan Iklim Madrasah secara signifikan terhadap peningkatan mutu madrasah.

$H_{0}$ : Int $A><B=0$ : Tidak terdapat konstribusi yang signifikan antara manajemen pembiayaan dan iklim madrasah secara Signifikan terhadap Peningkatan Mutu Madrasah.

$H_{a}$ : Int $A><B \neq 0$ : Terdapat konstribusi yang signifikan antara manajemen pembiayaan dan iklim madrasah secara signifikan terhadap peningkatan mutu madrasah.

Maka dapat dikatakan bahwa hasil pengujian menolak Ho dan atau menerima Ha. Dengan demikian, dapat disimpulkan bahwa terdapat konstribusi yang signifikan antara manajemen pembiayaan dan iklim madrasah secara signifikan terhadap peningkatan mutu madrasah. Hal ini dibuktikan kecenderungan variabel mutu pendidikan di Madrasah Aliyah adalah sebanyak $65 \%$ berada pada kategori tinggi, $19 \%$ sedang, dan $16 \%$ rendah. Dengan demikian, dapat disimpulkan bahwa kecenderungan variabel Mutu pendidikan berada pada kategori tinggi.

$\overline{\text { Al-Madãris, Volume 1 (1), } 2020}$ 


\section{E. Pembahasan}

1. Terdapat Konstribusi yang Signifikan antara Manajemen Pembiayaan terhadap Peningkatan Mutu Madrasah.

Manajemen pembiayaan adalah pengelolaan semua bentuk keuangan baik pemasukan dan pengeluaran yang secara langsung maupun tidak langsung untuk menunjang penyelenggaraan pendidikan, baik yang dikeluarkan oleh madrasah maupun siswa. Mutu madrasah adalah pendidikan yang mampu menghasilkan manusia seutuhnya (manusia paripurna) atau manusia dengan pribadi yang integral (integrated personality), yaitu mereka yang mampu mengintegralkan iman, ilmu, dan amal. Penelitian ini kecenderungan variabel manajemen pembiayaan di Madrasah Aliyah adalah sebanyak $35 \%$ berada pada kategori tinggi, $29 \%$ sedang, dan $35 \%$ rendah. Dengan demikian, dapat disimpulkan bahwa kecenderungan variabel Manajemen Pembiayaan berada pada kategori tinggi dan rendah. Dapat dikatakan mutu madrasah mengalami peningkatan.

\section{Terdapat Konstribusi yang Signifikan antara Iklim Madrasah terhadap Peningkatan Mutu Madrasah.}

Iklim madrasah adalah persepsi kolektif terhadap kualitas dan karakter dari kehidupan madrasah. Penelitian ini indikator yang digunakan untuk mengukur iklim madrasah adalah dengan menggunakan dimensi yang yang dikemukakan oleh coben, dengan alasan bahwa indikator tersebut merupakan indikator yang oleh penulis dipandang lebih terbaru dan lebih dapat menggambarkan ukuran dari konsep iklim madrasah sepuluh dimensi tersebut dikelompokkan ke dalam empat katagori, yaitu: (1) Kenyamanan, (2) Pembelajaran, (3) Hubungan antar pribadi dan (4) Lingkungan lembaga. Mutu madrasah adalah pendidikan yang mampu menghasilkan manusia seutuhnya (manusia paripurna) atau manusia dengan pribadi yang integral (integrated personality) yaitu mereka yang mampu mengintegralkan iman, ilmu, dan amal. Disimpulkan bahwa iklim sekolah/madrasah merupakan kehidupan sekolah/madrasah itu sendiri.

Pengalaman sekolah dalam menjalankan seluruh aktivitasnya, mulai dari norma-norma sekolah, pencapaian tujuan, hubungan antar civitas madrasah (kepala madrasah, guru, peserta didik, staf administrasi, penjaga madrasah, orang tua peserta didik), proses belajar mengajar, praktik kepemimpinan kepala madrasah serta struktur organisasi madrasah adalah refleksi atau gambaran dari apa yang disebut sebagai iklim madrasah. Seluruh pengalaman-pengalaman madrasah tersebut akan membentuk karakter madrasah atau kepribadian madrasah. Hubungan-hubungan antar civitas madrasah adalah hubungan sosial yang dibangun dalam rangka menjalankan berbagai aktivitas madrasah seperti, belajar mengajar, praktik kepemimpinan kepala madrasah, interaksi guru dengan peserta didik, interaksi guru dengan staf administrasi dan lain sebagainya.

Penelitian ini kecenderungan variabel Iklim Madrasah di Madrasah Aliyah adalah sebanyak $40 \%$ berada pada kategori tinggi, $31 \%$ sedang, dan $0 \%$

$\overline{\text { Al-Madãris, Volume l (1), } 2020}$ 
rendah. Dengan demikian dapat disimpulkan bahwa kecenderungan variabel Manajemen Pembiayaan berada pada kategori Sedang.

\section{Terdapat Konstribusi yang Signifikan antara Manajemen Pembiayaan dan Iklim Madrasah secara Signifikan terhadap Peningkatan Mutu Madrasah.}

Ditinjau dari sudut hukum, definisi pendidikan berdasarkan undangundang RI Nomor 20 tahun 2003 tentang Sistem Pendidikan Nasional (Sisdiknas),pasal l(1 dan 4) yaitu "Pendidikan adalah usaha sadar dan terencana untuk mewujudkan suasana belajar dan proses pembelajaran agar peserta didik secara aktif mengembangkan potensi dirinya untuk memiliki kekuatan spiritual keagamaan, pengendalian diri, keperibadian, kecerdasan, akhlak mulia, dan keterampilan yang diperlukan dirinya, masyarakat, bangsa dan negara. "Peserta didik adalah anggota masyarakat yang berusaha mengambangkan potensi diri melalui proses pembelajaran yang tersedia pada jalur, jenjang, dan jenis pendidikan".

Mutu di bidang pendidikan meliputi mutu input, proses, output, dan outcome. Input pendidikan dinyatakan bermutu jika siap berperoses. Proses pendidikan bermutu apabila mampu menciptakan suasana yang PAKEM (Pembelajaran yang Aktif, Kreatif, dan Menyenangkan). Output dinyatakan bermutu apabila hasil belajar akademik dan nonakademik siswa tinggi. Outcome dinyatakan bermutu apabila lulusan cepat terserap di dunia kerja, gaji wajar, semua pihak mengakui kehebatannya lulusannya dan merasa puas. Maka, konstribusi yang signifikan antara manajemen pembiayaan dan iklim madrasah secara signifikan terhadap peningkatan mutu madrasah, hal ini dibuktikan kecenderungan variabel mutu pendidikan di Madrasah Aliyah adalah sebanyak $65 \%$ berada pada kategori tinggi, $19 \%$ sedang, dan $16 \%$ rendah. Dengan demikian, dapat disimpulkan bahwa kecenderungan variabel mutu pendidikan berada pada kategori tinggi.

\section{F. Kesimpulan}

Berdasarkan dari rumusan masalah penelitian mengenai "Kontribusi Manajemen Pembiayaan dan Iklim Madrasah terhadap Peningkatan Mutu Pendidikan Madrasah Aliyah Negeri di Aceh Utara" dapat disimpulkan sebagai berikut. Pertama terdapat konstribusi yang signifikan antara manajemen pembiayaan terhadap peningkatan mutu madrasah. Hal ini ditandai oleh kecenderungan variabel manajemen pembiayaan di Madrasah Aliyah sebanyak $35 \%$ berada pada kategori tinggi, $29 \%$ sedang, dan $35 \%$ rendah. Dapat disimpulkan bahwa kecenderungan variabel manajemen pembiayaan berada pada kategori tinggi dan rendah dan dapat dikatakan mutu madrasah mengalami peningkatan. Kedua, terdapat konstribusi yang signifikan antara iklim madrasah terhadap peningkatan mutu madrasah. Hal ini ditandai oleh kecenderungan variabel iklim madrasah di madrasah aliyah adalah sebanyak $40 \%$ berada pada kategori tinggi, 31 \% sedang, dan $0 \%$ rendah. Dapat disimpulkan bahwa kecenderungan variabel manajemen pembiayaan berada pada kategori sedang. Ketiga terdapat konstribusi yang signifikan antara manajemen pembiayaan dan iklim madrasah secara signifikan

Al-Madãris, Volume 1 (1), 2020 
terhadap peningkatan mutu madrasah. Hal ini ditandai oleh kecenderungan variabel mutu pendidikan di madrasah aliyah adalah sebanyak $65 \%$ berada pada kategori tinggi, $19 \%$ sedang, dan $16 \%$ rendah. Maka, dapat disimpulkan bahwa kecenderungan variabel mutu pendidikan berada pada kategori tinggi.

\section{BIBLIOGRAFI}

Anwar Musfirah. (2016). Evaluasi Pembiayaaan Pendidikan. Jayapura: Uncen Press Arikunto Suharsini. (1993). Posedur Penelitian Suatu Pendekatan Praktek. Yogyakarta: Rineka Cipta

Davis, K. \& Newstroom, J.W.(1996). Perilaku dalam Organisasi, Terj. Agus Dharma, Jakarta: Erlangga

Departemen Pendidikan dan Kebudayaan. (1994). Kamus Besar Bahasa Indonesia. Jakarta: Balai Pustaka.

Fatah, Nanang. (2002). Ekonomi dan Pembiayaan Pendidikan. Bandung: Remaja Rosda karya

Hari Suderadjat. (2005). Manajemen Peningkatan Mutu Berbasis Sekolah; Peningkatan Mutu Pendidikan Melalui Implementasi KBK. Bandung: Cipta Lekas Garafika

Iwa Sukiswa. (1986). Dasar-dasar Umum Manajemen Pendidikan. Bandung: Tarsito

Lorry L. Hoffman. (2009). On Improving School Climate: Reducing Reliance on Reward and Punishment. Jurnal, Vol. 5 No. 3.

M. Richard Steers et al.(1995). Organizational Effectiveness: A Behavioral view. Goodyear Publishing Company Inc. Santa Monica. California. United Stated of America.

M. Tatang Amirin, dkk, (2013). Manajemen Pendidikan. Yogyakarta: UNY Press

Milner, Karen dan Khoza, Harriet. (2008). A Comparison of Teacher Stress and School Climate Across Schools with Different Matric Success Rates. South African Journal of Education. Volume 28. Jurnal.

Mujamil Qomar. (2007). Manajemen Pendidikan Islam. Malang: Erlangga.

Mulyana, E. (2002). Managemen Berbasis Sekolah. Bandung: Remaja Rosdakarya. ,(2012). Manajemen Kepemimpinan Kepala Sekolah. Jakarta: Bumi Aksara

Muzayyin Arifin. (2003). Kapita Selekta Pendidikan Islam. Jakarta: Bumi Aksara

Nanang Fatah. Indikator Kemandirian Pembiayaan Madrasah. Edukasi: Jurnal Penelitian Pendidikan Agama dan Keagamaan. Volume 5 nomor 1 (Januari-Maret).

Nanang Fattah. (2000). Ekonomi dan Pembiayaan Pendidikan. Bandung: Remaja Rosdakarya.

Natsir Armaya Siregar dan Mohd Saleh Sitompul. (2003). Reposisi dan Revitalisasi Madrasah dalam Jamaludin, Mendiskusikan Kembali Eksistensi Madrasah, Cet. II: Jakarta: Logos Wacana Ilmu.

$\overline{\text { Al-Madaris, Volume l (1), } 2020}$ 